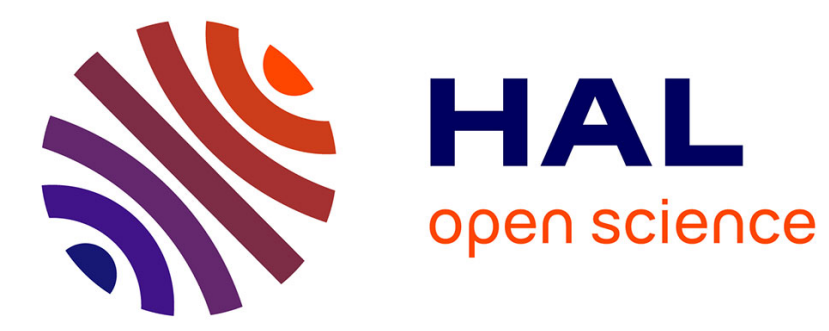

\title{
Do neighbourhoods have an influence on reproductive intentions? Empirical evidence from Milan
}

\author{
Silvia Meggiolaro
}

\section{To cite this version:}

Silvia Meggiolaro. Do neighbourhoods have an influence on reproductive intentions? Empirical evidence from Milan. Regional Studies, 2010, pp.1. 10.1080/00343401003713399 . hal-00605951

\section{HAL Id: hal-00605951 \\ https://hal.science/hal-00605951}

Submitted on 5 Jul 2011

HAL is a multi-disciplinary open access archive for the deposit and dissemination of scientific research documents, whether they are published or not. The documents may come from teaching and research institutions in France or abroad, or from public or private research centers.
L'archive ouverte pluridisciplinaire HAL, est destinée au dépôt et à la diffusion de documents scientifiques de niveau recherche, publiés ou non, émanant des établissements d'enseignement et de recherche français ou étrangers, des laboratoires publics ou privés. 


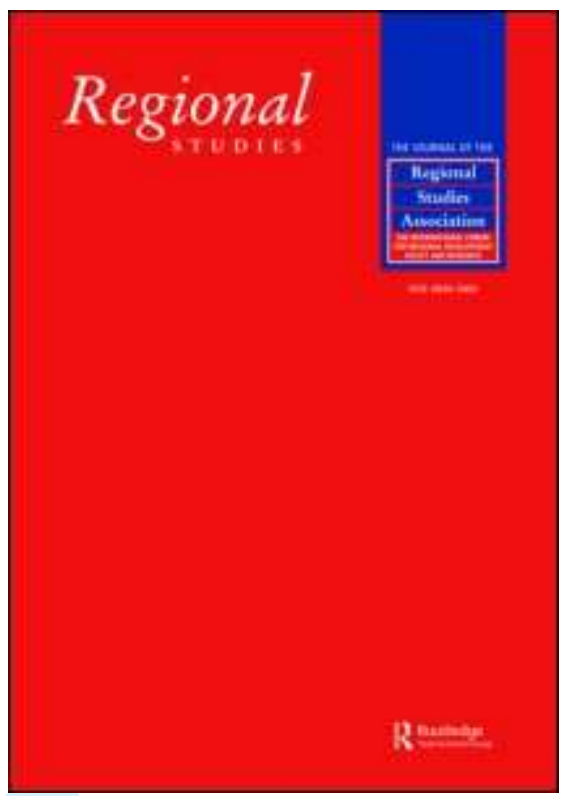

\section{Do neighbourhoods have an influence on reproductive intentions? Empirical evidence from Milan}

\begin{tabular}{|r|l|}
\hline Journal: & Regional Studies \\
\hline Manuscript ID: & CRES-2009-0020.R2 \\
\hline Manuscript Type: & Main Section \\
\hline JEL codes: & $\begin{array}{l}\text { R23 - Regional Migration|Regional Labor Markets|Population < R2 - } \\
\text { Household Analysis < R - Urban, Rural, and Regional Economics }\end{array}$ \\
\hline Keywords: & $\begin{array}{l}\text { reproductive intentions , contextual effects, sub-municipal detail, } \\
\text { Milan }\end{array}$ \\
\hline
\end{tabular}

\section{ScholarONE \\ Manuscript Central}




\title{
Do neighbourhoods have an influence on reproductive
}

\section{intentions? Empirical evidence from Milan}

\author{
Silvia Meggiolaro \\ Department of Statistical Sciences, University of Padova, Italy \\ Address: Department of Statistical Sciences, Via Cesare Battisti, 241, 35121, Padova, Italy \\ Phone ++390498274151, Fax ++390498274170, meg@ stat.unipd.it
}

(Received May 2008: in revised form December 2009) 


\begin{abstract}
This paper aims at studying the contextual effect on reproductive intentions with an innovative approach. It considers women and the groups to which they belong "close up", using data in very great territorial detail with reference to an Italian metropolitan area. This allows us to describe context in an in-depth and original way, thus examining the mechanism underlying the formation of fertility intentions.

Results suggest that, besides the importance of individual factors and preferences, reproductive choices are influenced also by some characteristics of the places in which individuals live.
\end{abstract}

KEYWORDS: reproductive intentions, contextual effects, sub-municipal detail, Milan.

JEL CODES: R23 - Regional Migration - Regional Labor Markets - Population

R2 - Household Analysis

R - Urban, Rural, and Regional Economics 


\section{INTRODUCTION}

Nowadays, studying the components of the decision to have or not to have a child may be very worthwhile. Reproductive intentions play a crucial role in the process of behaviour formation (BONGAARTS, 2001). This is particularly true in a context such as that obtaining in Western countries, where the decision to have a child increasingly becomes a conscious choice taken by individuals. Birth control, now common and accessible to most people, induces a feature of consciousness into fertility conduct which means that a component of prediction may be added to evaluations of reproductive intentions. Although some studies show that reproductive projects are prone to overestimate effective behaviour (FREEDMAN et al., 1980; WESTOFF and RYDER, 1977; MONNIER, 1987), in more recent analyses the high consistency of fertility intentions for subsequent behaviour is observed (SCHOEN et al., 1999; SYMEONIDOU, 2000; MENNITI, 2001).

Examining the formation of intentions about fertility is of interest. Studying reproductive orientation determinants may suggest the causes of low fertility levels (in Italy, they are among the lowest in Europe) and help to predict future behaviour.

This paper considers reproductive intentions, aiming at examining whether and how the characteristics of area of residence influence them. Individual orientations (and, in particular, reproductive intentions) may indeed be greatly affected by social context and reference groups such as family and neighbouring community, and larger geographical or administrative levels. Clearly, therefore, intentions should be contextualised, in order to understand demographic behaviour completely. Confirmation of the importance of context may also have considerable implications for future social policies.

In recent years, considerable attention has been focused on the contextual influence on demographic behaviour (for a review, see COURGEAU and BACCAINI, 1998). As regards reproductive behaviour, many studies suggest an analytical approach in which, besides individual characteristics, social norms, institutions, economic and environmental conditions have some 
effects (for example, MASON et al., 1983; SMITH, 1989; BILLY and MOORE, 1992; DE ROSE and RACIOPPI, 2001; HANK, 2002). Only a few authors consider the potential contextual effects on reproductive orientations (TESTA and GRILLI, 2006) and no studies look at neighbourhood effects on fertility intentions in European cities.

Similar observations may be made considering Italy. It is widely acknowledged that fertility level determinants not only exist at individual level (DE ROSE, 1997; SORVILLO, 1997; RIVELLINI and ZACCARIN, 1999) but there are no studies on the effect of living context on reproductive intentions. In addition, Italian literature considers administrative macro-units such as those set up by municipalities or provincial authorities, since usually available data do not refer to greater territorial detail. In fact, a very local perspective may be necessary in order to study in-depth complex mechanisms such as those underlying the formation of reproductive orientations. As some authors have suggested the influence of the contextual dimension which is the closest to individuals should be considered $^{1}$ (BONGAARTS and WATKINS, 1996; LEE et al., 1994). In this way, individuals, the groups to which they belong, and the communities in which they live may be examined "close up". In some cases, however, considering great territorial detail may lead to causality issues: for example, individuals may have based their neighbourhood choice on their fertility intentions. This is probably not the case in Italy, due to the rigidity of the Italian housing and to the high proportion of home-owners (ISTAT, 2007): in this context, moving costs are very high and consequently, once individuals have bought their own home and moved into it, moving elsewhere simply only because of their reproductive intentions is not very common.

This paper represents the first attempt to consider less standard information in greater territorial detail than that usually available, to analyse the effect of the context of residence on reproductive intentions. Thus, the context is described in an in-depth and original way, considering richer data than that used in usual ecological surveys. This is thanks to the possibility of exploiting a particular individual and contextual data source system with reference to a metropolitan area in Northern Italy (the city of Milan), allowing simultaneous study of micro- and macro-aspects at a 
very detailed territorial level. From this point of view, Milan is the occasion for innovative contextual analysis, since this metropolis has appropriate and useful features. Besides the availability of considerable information about demographic, economic and social phenomena at sub-municipal detail, Milan has typical features for contextual analysis. It covers more than 180 sq. $\mathrm{km}$., has a population of more than $1,200,000$ (population registry at 31/12/2003) and a high population density (about 7,000 persons/sq. km.). This means that very heterogeneous neighbourhoods (and people), each with their own social and cultural identities, co-exist. Individuals living in different areas may be presumed to be influenced in different ways in their choices. In addition, Milan, being a large metropolitan area, can act as a precursor for behaviours and trends.

The aims of this paper are reached through two types of data: individual and contextual. Individual data came from a survey conducted in Milan in 2000, giving information on the individual characteristics and reproductive intentions of a sample of women living in the city. Contextual data sources were analysed to describe the neighbourhoods in which they live. These data allow us to consider short-term reproductive intentions and to study how they may be influenced by the characteristics of the place of residence ${ }^{2}$.

The remainder of this paper is organised as follows. Section 2 discusses the importance of macro-factors in understanding fertility choices, in the light of hypotheses and empirical results in the literature. Section 3 describes data and models used in the analysis. Individual and contextual determinants of fertility intentions are examined in Section 4, which is followed by a Discussion and Conclusions in Section 5.

\section{THE ROLE OF CONTEXT IN FORMING REPRODUCTIVE ORIENTATIONS AND BEHAVIOUR: BACKGROUND AND HYPOTHESES}

The conceptual framework guiding this analysis follows the framework used in the literature on possible contextual aspects influencing reproductive behaviour and intentions. Here, that 
framework is extended to incorporate a more detailed description of the effects of potential neighbourhood factors influencing short-term reproductive intentions (see note 1). In particular, four complex contextual dimensions are considered. Although they refer to different aspects, they also show some partial overlaps.

First of all, theory and previous research suggested the role of social norms in determining reproductive choices: we refer to social interactions (BONGAARTS and WATKINS, 1996; MONTGOMERY and CASTERLINE, 1998). According to this process, women living in neighbourhoods with "post-modern" demographic characteristics (e.g., an older population, or many single-parent families) may be more prone to having lower fertility levels, whereas neighbourhoods with more children may lead women to similar behaviour (RIVELLINI and ZACCARIN, 1999). This hypothesis is extended here to reproductive intentions and may be examined by considering the demographic structure of the area of residence.

The second contextual dimension refers to the balance of costs and benefits of having children.

As regards costs, we may presume that neighbourhoods with better services and structures favour the presence of children, and consequently influence women positively in their reproductive choices. In this situation, available services become a support for families with children, reducing their costs. Thus, examining community level characteristics related to the existence of formal services may be worthwhile (although some services may have a larger scope than just neighbourhoods). This hypothesis is not confirmed at micro-level in the literature (in the case of Italy, see ONGARO, 2004), but it is often used to explain differing fertility levels in European countries: higher in the north of Europe (CONSEIL de L'EUROPE, 2000) and lower in Mediterranean countries ${ }^{3}$. Similar observations may be noted, considering informal services and aspects connected with the social network. For example, the presence of children in neighbourhoods may decrease the high cost of having children, because some care activities are shared in a network with the same necessities. In line with these remarks, it may also be interesting to examine women's 
participation in the labour market ${ }^{4}$ : in areas with high female occupation rates, fewer women are available for informal networks, so that residents may be less disposed towards having children because they feel that the neighbourhood network, which should help with children's care, is less strong. In fact, high female labour market participation may lead to the development of family services, to cater for working mothers' needs, so that the intention of having a child may increase, because opportunity costs decrease.

As regards benefits, in present-day society, children have psychological and social value rather than an economic benefit value. Their advantages are more difficult to observe in comparison with costs and, in particular, "the pleasure of children" is more evident for people living in neighbourhoods characterised by many children (ONGARO, 2006). It may be presumed that, in these contexts, the reproductive intentions of individuals are higher.

Another contextual dimension (which is partly connected with the cost-benefit balance) refers to trust in or fear of the future. Living in situations of unesase or social degradation or in areas of low socio-economic status may create a climate of fear of the future. Women living in such areas may suppress their desire to have children, to protect themselves from the problems of children (or of the family). In comparison with the researches mentioned above, in this paper the aspect of trust in the future is analysed in more depth, also considering the social vitality of the residence community. The environment may support friendly relationships among residents, so that they form groups. Individuals who feel lonely or isolated may have less faith in their neighbours and in the future, and are thus presumed to have lower fertility intentions. The opposite may happen among individuals living in a positive social context, which produces a situation of security and a sense of protection (for a review of studies on neighbourhood effects of social cohesion and social problems, see SAMPSON et al., 2002).

Lastly, an important contextual dimension is the cultural one. VAN DE KAA (2001) attributes low fertility choices to post-modern and post-materialist values, according to which the centre of the preference system is individualism, in contraposition to more altruistic, traditional 
values which, for example, are expressed in the desire to have a child. However, having children may be viewed positively by post-materialist individuals, as it may constitute an important element in their perception of well-being and self-realisation. Various characteristics of the place of residence may be connected with this dimension. Again, the level of female occupation may be an important indicator: where women's labour market participation is high, we expect to find a value system in which the propensity for having children is low (the value of work may be in competition with the values of the family and of children). In fact, this hypothesis is not confirmed from a macro point of view (see AHN and MIRA, 2002).

\section{DATA AND METHODS}

\subsection{DATA SOURCES}

The data used in this paper are numerous and of various natures.

Individual data refer to the Survey "Fecondità e Contesto: tra certezze e aspettative" ("Fertility and Context: certainties versus expectations"), conducted in Milan in 2000. This survey was a re-proposal at local level of the "Second national survey on fertility control and expectations" (Inf-2, DE SANDRE et al., 1999) of the international project started in the 1990s, "Fertility and Family Survey" project. The sample is made up of women living in Milan, between 20 and 49 years old, and some of their partners (for details about sampling, see ROSSI, 2001, and SEMISA, 2003), and is representative of the city. Data for women from the Survey are used here for information about individual characteristics and, in particular, about short-term fertility intentions.

Contextual data are considered to describe the neighbourhoods in which the women live. The area of residence is known for each woman. In particular, this paper refers to the administrative division of Milan into 20 districts (used until 1999; see figure 1). Many sources of various natures are available: administrative (e.g., personal and electoral data), those provided by two data banks of the "Statistical Sector" of Milan (Sistema Informativo Infanzia e Adolescenza - Childhood and Youth Informative System, and Banca Dati Anagrafe Scolastica - School Registry Data Bank), 
data related to the 2001 Population Census, and data obtained from two departments of Milan ("Parks and Gardens" and "Decentralised Sectors").

(Figure 1 about here)

\subsection{INDIVIDUAL DATA}

Survey data yield information on the reproductive intentions and individual characteristics of a sample of 839 women resident in the municipal area of Milan. Data about reproductive intentions were obtained for 790 women, the focus of this paper $(5.8 \%$ of interviewees did not answer this question because they were infertile for non-contraceptive reasons). Table 1 lists the distributions of some of their characteristics, which are used in subsequent analyses.

(Table 1 about here)

Reproductive intentions were obtained by considering two questions of the survey. The first question asked every interviewee if she intended to have children in the next few years; if she answered positively, she was asked to specify when she would like to have her first/next child. Matching these two questions, women were grouped into four categories: women with short-term intentions of having children (within 3 years), women with more long-term intentions (over 3 years), uncertain women, and women who did not intend to have any (more) children. This paper focuses on short-term intentions, because they probably express more realistic orientations, having strong consistency with subsequent fertility. Table 1 shows that about $25 \%$ of women want to have (more) children within the next three years.

It is interesting to note (table 2 and figure 2) that this percentage varies considerably across the districts of residence. Clearly, the differences may be due to the relatively small sample size in 
some districts. In fact, the differences may be explained by differences in demographic composition across districts. Lastly, there may be a contextual effect, which is the focus of this paper. Before concentrating on this effect, the potential individual determinants of short-term intentions are considered.

(Table 2 about here)

(Figure 2 about here)

Obviously, short-term fertility orientations vary considerably, according to some basic demographic characteristics such as women's age at the survey, parity, and family situations. In particular, as regards the latter, in the following some characteristics such as marital status, marital duration and intentions of marrying are considered ${ }^{5}$. In a context like the Italian one, about $90 \%$ of births occur within marriage (GESANO et al., 2007), and at least one birth occurs during the first few years of most marriages (KERTZER et al., 2006). Therefore, married women (especially in the first years of marriage) are expected to express short-term intentions at a greater rate than women in other positions. Similar observations may be made for women planning to marry.

Two variables are then examined to take into account women's socio-economic status: education and employment status. Education is expected to broaden individuals' perception of life by making them aware of career opportunities and of the possibilities for self-fulfilment in many other ways (different from childbearing). In addition, the time devoted to children may be perceived as competing against other opportunities (HOTZ et al., 1997). Consequently, women achieving a high educational level are presumed to prefer smaller families, compared with less educated women. In the same way, employed women are expected to be oriented towards lower fertility levels in comparison with housewives. In fact, some studies suggest that educational level is an important factor in determining the timing but not the quantum of family formation (see, for example, SKIRBEKK et al., 2004). 
Religious participation is considered to show whether religious feelings strengthen the fundamental values attributed to children and thus increase fertility perspectives (SORVILLO and MARSILI, 1999).

Besides variables about interviewees' socio-demographic and socio-economic characteristics, other variables which may influence fertility orientations are also controlled for. In particular, some characteristics of the original family are examined, to describe women's family and cultural models (number of children of interviewee's mother, and separated or divorced parents). The underlying hypothesis is that the family of origin is an example, so that some attitudes are repeated and imitated. In addition, these variables are indicators of the women's social background.

Lastly, a variable representing women's social and neighbourhood network may be important (presence of friends to call upon for small needs).

\subsection{CONTEXTUAL DATA: SIMPLE INDICATORS AND COMPOSITE}

\section{INDEXES}

As mentioned above, contextual data refer to the administrative division of Milan into 20 districts. Each administrative districts was defined by a number (from 1 to 20): as figure 1 illustrates, district 1 corresponds to the historic centre of the city, districts $2,3,4,5$ and 6 form a sort of ring immediately round the centre, and the other districts are suburbs. The size of the districts differs greatly. Their average population was about 63,000 , varying from 23,000 to 98,000 (Table 2). They cover 9.1 sq. $\mathrm{km}$ on average, varying from 2.5 to 20.1 sq. km (Table 2).

These 20 districts are described through various simplex indicators (appendix A lists elementary data, data sources and year of reference ${ }^{6}$ ) bearing in mind the four contextual dimensions considered in section 2.

First, some information referring to demographic structure (e.g., age, type of family, marital status of residents) examines the role of social norms and social interaction. 
As regards the contextual dimension referring to cost-benefit analysis, data on cultural, sports, children's services, and environmental quality are taken into account.

To identify districts creating a climate of serenity and faith in the future (the third dimension of section 2), three aspects are considered. The first describes "social unease", by which we mean, for example, the presence of children who miss one school year, situations of problems with minors and families in difficulty, followed by the social services. The second aspect examines the socioeconomic context: data was collected on (female and male) jobs, education and housing conditions. The third aspect describes social cohesion, considering the presence of groups such as church organisations and community centres.

Lastly, the cultural dimension is described through electoral behaviour ${ }^{7}$ (with reference to the election of the Chamber of Deputies, 13 May 2001).

In this way, six thematic areas were defined (thematic areas are used to describe a context by several authors, e.g., ZAJCZYK, 1997, and VITALI and MERLINI, 1999):

$\checkmark$ demographic structure;

$\checkmark$ services and environmental quality;

$\checkmark \quad$ social unease (i.e., problem areas, trouble spots);

$\checkmark$ socio-economic context;

$\checkmark$ community vitality;

$\checkmark$ electoral behaviour.

Once a batch of simple indicators had been obtained for each area (see appendix A), the problem was to compose a single batch.

Several methods may be used, some based on factor analysis (GNANADESIKAN, 1977; ZELLER and CARMINES, 1980; FERGANY, 1994). Other important techniques may be found in the order procedures used to describe life quality by VITALI and MERLINI (1999) and AIELLO and ATTANASIO (2004). 
Methods based on factor analysis may be used, because it studies the interrelationships among a group of variables in order to describe them in terms of common dimensions. It "extracts" factors or dimensions from the original variables, reducing them to a small number of factors that can serve as composite variables. In the present paper, the first two factors, which explain the highest amount of variance in the original data, are extracted for each thematic area examined by factor analysis. The factor structure matrixes (appendix B) may be considered to interpret factors. In particular, for the demographic area, the first indicator is found to be connected with family types, and the second with demographic ageing: positive values denote "post-modern" characteristics (section 2). As regards social unease, the first contextual factor is associated with severe situations of unease, the second factor refers to less severe ones: for both indexes negative values are indicative of the absence of unease situations. The first indicator of the socio-economic context measures socio-economic level (and is positively associated with disadvantaged conditions); the second may be used to represent female participation in the labour market (appendix B suggests that positive values of this factor refer to high female participation). Lastly, as regards the two electoral dimensions, the first is related to the opposition between Right and Left parties (negative values denoting right-wing views), and the second to the different conception and ideas of community solidarity observed among political parties (positive values referring to solidarity).

The two remaining areas (services and community vitality) are conflated by another method which is based on an order procedure. It is more proper to conflate non-correlated indicators (such as those relating to services and social vitality). This method may be divided into two phases: the first is a transformation aiming at the comparability of different measures, and the second examines the process of reconstruction of single indicators to a composite indicator, through a link function. Therefore, the first transformation yields dimensionless data which, through the second function, can be combined into one, which is a measure of the underlying concept (for details, see VITALI and MERLINI, 1999). This technique does not use different weights for the various simple 
indicators; however, it has been shown to provide robust measures. Thus, we obtain two indicators, which describe services and community vitality.

Table 3 lists these processes of variable construction, reporting some information and statistics for the contextual indexes of the six thematic areas considered here.

(Table 3 about here)

\subsection{METHODS}

As analysed in section 2, in this study it makes sense to take the hierarchical structure (defined by the woman's district of residence) into account. In fact, a micro-macro scheme (COLEMAN, 1990) may be used, since individual and contextual levels interact with each other. In this paper, however, only the macro-micro direction is considered, studying the potential effect of the context of residence. In the following, to examine how this is obtained, $p$ is the probability of expressing the short-term intention of having children, $x$ is the covariate at the individual (woman) level, and $z$ is the explicative variable at the context (district of residence) level. Subscript $i$ stands for individual (in this case $i=1, \ldots, 790$ ) and $j$ for context (here, $j=1, \ldots, 20$ ).

A first "traditional" way of analysing our grouped data includes both levels (district of residence and woman level), but not in equal roles. Individual level covariates are involved as in regression models, but at the same time contexts (defined by the districts of residence) are allowed to differ in the intercepts. In this model, dummy variables are used to code group membership:

$$
\operatorname{logit}\left(p_{i j}\right)=a_{j}+b x_{i j}
$$

where $a_{j}$ denotes a different intercept for each context $j$ (in fact, in model estimation, a constant and 19 dummy variables, which correspond to the districts from 2 to 20 , are used: in this way, districts 1 


$$
a_{j}=\gamma_{00}+\gamma_{01} z_{j}
$$

Note that we actually fit a single model, which becomes clear when we substitute macroequation (2) into micro-equation (1). We obtain the single equation:

$$
\operatorname{logit}\left(p_{i j}\right)=\gamma_{00}+\gamma_{10} x_{i j}+\gamma_{01} z_{j}
$$

Of course, in the models used here, there is more than one covariate on both levels.

Random effects at group level (as in multilevel models; see, for example, SNIJDERS and BOSKER, 1999) are not used. Instead, a fixed-effect model with contextual variables (a particular case of the random coefficient model; KREFT and DE LEEUW, 1998) is considered. This model is more appropriate in cases such as ours, in which second-level units (the 20 districts of residence) are not a sample from a wider population, but the only groups of interest. This does not mean that the intra-cluster correlations embedded in the data structure are not taken into account in parameter estimation $^{8}$.

In fact, there may be a methodological limitation in this paper. Studies seeking to assess the effects of contextual factors need to have large samples of groups, since the number of groups does have more effect on statistical power than the number of observations (CLARKE and WHEATON, 2007), although both are important, and both adequate numbers of individual observations and 
adequate numbers of groups are needed. However, HOX (1995) suggests that the higher-level (group-level) sample size be at least 20; but simulation studies by KREFT (1996) found that there was adequate statistical power with 30 groups of 30 observations each. Although in this paper group level sample size is included in the lower bound by HOX (1995), according to KREFT's study (1996) it may influence the stability of results. A Bayesian approach may be the solution; in fact, here the stability of the results is ensured by estimating fixed effects models 9 .

\section{RESULTS}

\subsection{INDIVIDUAL DETERMINANTS OF SHORT-TERM REPRODUCTIVE INTENTIONS}

A logistic regression model describes the probability of expressing the intention of having a child within 3 years. The selection of parameters to be included in the model is obtained with parsimony; a model with single effects and some interaction effects is chosen, avoiding higherorder interactions for simpler interpretation of results.

Table 4 lists the estimates of the coefficients for the final model with single effects (no interaction was significant).

(Table 4 about here)

Confirming literature data (see, for example, DE SANDRE et al., 1997), age has a significant effect on short-term reproductive intentions. In fact, a non-monotonic effect is found: it suggests that the highest probability of expressing a short-term intention of having children is found among women aged 30-34. Women under 30 and women aged 35-39 are almost three times (respectively, $\exp (1.12)=3.1$ and $\exp (1.02)=2.8)$ as likely to express the intention of having children in the short term than those in the reference group (40 or over). The non-monotonic effect may be due to the fact that only short-term reproductive intentions are considered. Younger women 
rarely express plans for not having children, but they are likely to have future expectations, particularly at more than 3 years.

The effect of children already born is also highly discriminating. In particular, women who have already had two or more children have an odds ratio $($ o.r $)$ of about one-fourth $(\exp (-1.54)=$ 0.21) that of childless women of expressing the intention of having more children within the next 3 years; the mothers of only one child do not show a different propensity in short-term intentions in comparison with women without children.

Women married for less than 5 years (or those who are planning to marry) are more prone to express intentions of having children soon, rather than never married women (who do not plan to marry in the next two years). The long duration of a marriage and the state of the end of an union have the same effects as those observed for never married women ${ }^{10}$.

The other covariates have no significant effects. This result is unexpected, in particular, as regards the variables on socio-economic status and on church attendance.

As regards socio-economic status variables (education and employment status), the unexpected results may be connected with the low fertility level which characterises Italy (women of the sample have a lower fertility level than the national one; DE SANDRE and ONGARO, 2003). For example, a negative association is usually presumed between female labour force participation (or, generally, human capital variables) and fertility in the incompatibility of rearing children and staying in the workforce in today's society. However, several recent studies have suggested that the link between fertility and female employment is weakening, due to the greater availability of childcare services, family policies, changing attitudes towards working mothers, and changing gender roles (VIKAT, 2004; SANTOW and BRACHER, 2001). In particular, in some countries women may be able to combine work and childrearing more successfully. In addition, women's economic independence (due to their participation in the labour market) may promote fertility, granting economic resources and security also in perspective terms (see SALVINI, 2004). Many studies have indeed found a positive relationship between female earnings and childbearing 
(for example, ANDERSSON, 2000 and VIKAT, 2004). In the present study, Milan, with the typical features of large metropolitan areas, may act as a precursor of innovative trends: the presence of innovative aspects may remove the traditionally negative effect of human capital variables on fertility orientations.

Although coefficients of church attendance are all positive, they are not significant. Again, this result was unexpected (the literature shows significant effects, e.g., SORVILLO and MARSILI, 1999) and should be studied in depth in future researches. In any case, a preliminary supposition is made, as there may be a spurious effect of the high intercorrelation of religious participation and children already born ${ }^{11}$.

\subsection{SHORT-TERM REPRODUCTIVE INTENTIONS AND THE EFFECT OF CONTEXT}

Using model (1) described in paragraph 3.4 with the specification of a constant and 19 dummy covariates (districts 2-20), we analyse whether there are any differences in short-term reproductive intentions according to women's areas of residence ${ }^{12}$. Results are listed in table 5 . With respect to the model with individual variables only, there are no great differences in individual level coefficient estimates (except for the significance of the effect of employment status), but it is interesting to examine the differences among the districts ${ }^{13}$.

(Table 5 about here)

Figure 3 represents these differences. Most districts show lower proportions of women with short-term intentions of having a child in comparison with districts 1 (historic centre of the city which represents the reference category): these are the districts immediately adjacent to city centre (districts 2-6) and some in the suburbs (e.g., districts 7, 9, 10, 14, 16). Only (suburban) districts 12 and 15 have significantly higher percentages of women who intend to have children within 3 years, 
in comparison with the centre: for example, women in suburban district 12 are almost two times $(\exp (0.58)=1.8)$ more likely to intend to have children within three years compared with women living in the city centre (everything else remaining constant).

(Figure 3 about here)

Thus, a contextual component may be seen in reproductive intentions. The next step lies in examining which contextual covariates explain these differences. Contextual model (3) is applied, referring to the contextual variables described in paragraph 3.3 (see table 3). Table 6 lists the results. Only two contextual variables turn out to be significant. The first is related to the less severe situations of minor unease, and the second describes community social cohesion ${ }^{14}$.

(Table 6 about here)

Women living in districts characterised by less social unease are more prone to express short-term intentions of having children than women resident in districts with some forms of unease (high rates of school drop-out, many minors followed by the social services, etc.).

In addition, the more a community is vital and characterised by social cohesion, the more frequently resident women are prone to short-term projects for having a child.

Although this result is very interesting and not completely expected, it must be interpreted with caution. The individual-level counterpart of the latter contextual variable (representing social and neighbourhood network of women) was included in the model describing individual determinants of reproductive intentions and table 4 shows that it had not influence on women's short-term reproductive intentions. Unfortunately, the individual-level counterpart of social unease cannot be included because of a lack of proper data. Individual aspects connected with family background may be presumed to control, at least partly, individual unease. 
The other contextual variables have no significant effects. In particular, social interactions, described by the demographic structure of the place of residence, do not seem to be important. The presence of services, as supports for families with children, is probably not perceived as a determinant factor in childbearing plans (moreover, the presence of services in the place of residence may be not as important as, for example, the presence of services in the place of work; or, as mentioned in Section 2, some services may cover more than only one district). Lastly, the cultural and the socio-economic dimensions of the place of residence do not influence women as regards fertility intentions.

\section{CONCLUSIONS}

This paper aims at studying the contextual effect on reproductive intentions with an innovative approach. It considers women and the groups to which they belong "close up", using data in very great territorial detail. This detail allows us to describe context in an in-depth and original way, thus examining the mechanism underlying the formation of fertility intentions.

Results suggest that there are some contextual aspects influencing women's short-term reproductive orientations. In particular, the idea that emerges from this study is that, besides the importance of individual factors and preferences, the intention to have a child is probably taken only in conditions of well-being and serenity, which do not derive only from individuals but also from some characteristics of the places in which they live.

On one hand, these conditions may be reached by avoiding some forms of unease: the hypothesis of a "prudent" point of view, according to which women living in problematic environments are less likely to express positive reproductive intentions, as if to protect themselves from problem situations such those they observe in their residential context.

On the other hand, well-being and serenity may only be achieved in the context of a vital community characterised by social cohesion. Feeling part of a group produces a sense of security and protection, trust in the future, the ideal "climate" for thinking about having a child. Conversely, 


\begin{abstract}
living in a context where women feel alone or isolated is associated with a lower probability of making a "demanding" choice such as that of having (more) children.
\end{abstract}

Clearly, in the current context of low fertility, understanding what kind of evaluation women make in the decision to have a child or not is not easy. In addition, the mechanisms which form fertility intentions should also be examined within a couple perspective (which is not considered here because of the lack of proper data about partners). However, this paper suggests that a context which allows women to feel confident about the future may allow them to feel ready to face the uncertainties connected with their choices. In this way, social policies may play an important role. In particular, interventions aimed at creating a serene environment and thus at supporting families with children are worthwhile. Structured actions (that go further than strictly economic aspects), in which the definite will of society to share and support the role of mothers is clearcut, may induce in them that greater serenity, sense of trust in the future and security, which all go towards forming the ideal climate to think about having children.

\title{
ACKNOWLEDGEMENTS
}

The author would like to thank Fausta Ongaro and Nicola Torelli for helpful and valuable comments on the drafts of this paper, and Stan Panis for his useful suggestions on aML use and model specification. I would also like to thank the associate editor and two anonymous referees for their comments that greatly improved this paper.

\footnotetext{
${ }^{1}$ Concerning this remark, a previous study with reference to Milan showed some neighbourhood effects in the process of loneliness perception among the elderly population (MICHELI and RIVELLINI, 2001).

${ }^{2}$ Short-term (rather than long-term) reproductive intentions are more probably affected by context than long-term intentions: the latter does represent more deep-rooted orientations and consequently may be less influenced by contextual aspects.
} 


\footnotetext{
${ }^{3}$ In Northern European countries, social-democratic welfare governments are more prone to reconciling female labour market participation and children, with intervention to the advantage of families. Conversely, Mediterranean countries
} are characterised by conservative welfare (ESPING-ANDERSEN, 1999).

${ }^{4}$ As regards the effect of resident employment status, there are various theories on how they may influence fertility at micro- and macro- levels, and hypotheses are not always univocal (see BREWSTER and RINDFUSS, 2000, for a review of the effects of women's participation in the labour market).

${ }^{5}$ There is clearly a biunivocal relation between childbearing (plans) and marriage/divorce decisions (i.e., there may be a causality problem). However, reproductive intentions are reached differently according to marital status, and must be standardised.

${ }^{6}$ The reference to different years is not a limitation, as the social phenomena considered here change slowly over time.

${ }^{7}$ The underlying hypothesis is that there is a link between the political-cultural climate of residence and the values systems of individuals. This hypothesis requires some caution: it presumes that there is not only an association between political orientations and the values system, but that this association also has consequences on the reproductive behaviour of individuals. In Italy, confirmation of this hypothesis is found at macro level, considering the link between referendum choices and reproductive behaviour (see MANNHEIMER et al., 1978, on the vote expressed for the 1974 abrogative referendum on divorce; LIVI BACCI, 1980; DALLA ZUANNA and RIGHI, 1999).

${ }^{8}$ In particular, with aML software (LILLARD and PANIS, 2003), the multilevel residual structure is an explicit feature of the estimation procedure.

${ }^{9}$ However, preliminary analyses considering models with random effects, estimated by means of an approximation of the likelihood given by the numerical integration of residuals and based on Gauss-Hermite quadrature (see ABRAMOWITZ and STEGUN, 1972), give similar results, with negligible variance of random components.

${ }^{10}$ Never married women also include women in consensual unions, as in preliminary analyses they do not show different reproductive intentions with respect to never married women who do not live with a partner.

${ }^{11}$ A close association is indeed observed between women who have already achieved high fertility (with three or more children) and women who go to church regularly. The variable parity, included in the model, distinguishes women without children, women with one child, and women with two or more children. Among the latter category are women with three (or more) children: most of them regularly attend church, but they have already achieved satisfactory fertility and so do not want other children. This may lead to the spurious effect observed in the model. However, it was not possible to distinguish women with two children from women with three or more children, due to the small sample size.

${ }^{12}$ aML software was used (LILLARD and PANIS, 2003). 


\footnotetext{
${ }^{13}$ In addition, the measures of association between predicted probabilities and observed responses, listed in the last row of the table, show how this model is improved with respect that of table 4.

${ }^{14}$ It is interesting to note that districts 12 and 15, where higher percentages of women who intend to have children in the short term were found by the previous model (table 5), are characterised by a low level of social unease and a high level of community vitality (for details, see MEGGIOLARO, 2005).
} 


\section{REFERENCES}

ABRAMOWITZ M. and STEGUN I. A. (1972) Handbook of Mathematical Functions, Dover Publications, New York.

AHN N. and MIRA P. (2002) A note of the relationship between fertility and female employment rates in developed countries, Journal of Population Economics 15 (4), 667-682.

AIELLO F. and ATTANASIO M. (2004) How to transform a batch of simple indicators to make up a unique one? in Atti della XLII Riunione Scientifica SIS, pp. 327-338. Università di Bari, 9-11 giugno 2004, Bari.

ANDERSSON G. (2000) The impact of labour-force participation on childbearing behaviour: procyclical fertility in Sweden during the 1980s and the 1990s, European Journal of Population 16 (4), 203-333.

BILLY J. and MOORE D. (1992) A multilevel analysis of marital and nonmarital fertility, Social Forces 70 (4), 977-1011.

BONGAARTS J. and WATKINS S. C. (1996) Social interactions and contemporary fertility transitions, Population and Development Review 22 (4), 639-682.

BONGAARTS J. (2001) Fertility and reproductive preferences in post-transitional societies, in BUlATAO R. A. and CASTERLINE J. B. (Eds.) Global fertility transition, pp. 260-281. Population Council: New York.

BREWSTER K. L. and RINDFUSS R. R. (2000) Fertility and women's employment in industrialized nations, Annual Review of Sociology 26, 271-296.

CLARKE P. and WHEATON B. (2007) Addressing data sparseness in contextual population research using cluster analysis to create synthetic neighborhoods, Sociological Methods and Research 35 (3), 311-351.

COLEMAN J. (1990) Foundations of Social Theory, Harvard University Press, Cambridge.

CONSEIL DE L'EUROPE (2000) Evolution Démographique Récente en Europe, Conseil de l'Europe, Paris. 
COURGEAU D. and BACCAINI B. (1998) Multilevel analysis in the social sciences, Population $10(1), 39-71$.

DALLA ZUANNA G. and RIGHI A. (1999) Nascere nelle cento Italie. Comportamenti coniugali e riproduttivi nelle province italiane negli anni ' 80 e '90, Istat n. 18, Roma.

DE ROSE A. (1997) Scelte di fecondità e di infecondità: i fattori determinanti individuali e di contesto, In GIORGI P. and STROZZA S. (Eds.) Studi di popolazione. Temi di ricerca nuova, pp. 31-50. Secondo Convegno dei giovani studiosi dei problemi di popolazione. 25-27 giugno 1996, Dipartimento di Scienze Demografiche, Università degli Studi di Roma "La Sapienza”, Roma.

DE ROSE A. and RACIOPPI F. (2001) Explaining voluntary fertility in Europe: a multilevel approach, Genus LVII (1), 13-32.

DE SANDRE P., ONGARO F., RETTAROLI R. and SALVINI S. (1997) Matrimonio e figli: tra rinvio e rinuncia, Il Mulino, Bologna.

DE SANDRE P., PINNELli A. and SANTINI A. (Eds.) (1999) Nuzialità e fecondità in trasformazione, percorsi e fattori del cambiamento, Il Mulino, Bologna.

DE SANDRE P. and ONGARO F. (2003) Fecondità contraccezione, figli attesi: cambiamenti e incertezze, in Fecondità e contesto: tra certezze e aspettative. Dalla "Seconda Indagine Nazionale sulla Fecondità” alla realtà locale, pp. 27-56. Comune di Milano, Settore Statistica, Quaderno di documentazione e studio n. 38, Franco Angeli, Milano.

ESPING-ANDERSEN G. (1999) Social Foundations of Post-Industrial Economies, Oxford University Press, Oxford.

FERGANY N. (1994) Quality of life indices for Arab countries in an international context, International Statistical Review 62 (2), 187-202.

FREEDMAN R., FREEDMAN D. S. and THORNTON A. D. (1980) Changes in fertility expectations and preferences between 1962 and 1977: their relation to final parity, Demography $17(4), 365-378$. 
GESANO G., ONGARO F. and ROSINA A. (Eds.) (2007) Rapporto sulla popolazione. L'Italia all'inizio del XXI secolo, Il Mulino, Bologna.

GNANADESIKAN R. (1977) Methods for Statistical Data Analysis of Multivariate Observations, Wiley \& Sons, New York.

HANK K. (2002) Regional social contexts and individual fertility decisions: a multilevel analysis of first and second births in Western Germany, Diw Discussion Paper No. 270, Max Planck Institute for Demographic Research, University of Rostock, Germany.

HOTZ V. J., KLERMAN J. A. and WILLIS R. J. (1997) The economics of fertility in developed Countries, in ROSENZWEIG M. R. and STARK D. (Eds.) Handbook of Population and Family Economics, pp. 275-308. Elsevier Press, New York.

HOX J. J. (1995) Applied Multi-level Analysis, 2nd Ed. TT-Publikaties, Amsterdam.

KERTZER D., WHITE M., BERNARDI L. and GABRIELLI G. (2006) Italy's path to very low fertility. The adequacy of economic and second demographic transition theories, WP-2006-049, Max Planck Institute for Demographic Research, Rostock, Germany.

KREFT I. (1996) Are multi-level techniques necessary? An overview, including simulation studies, California State University, Los Angeles.

KREFT I. and DE LEEUW J. (1998) Introducing Multilevel Modelling, Sage Publications, London. ISTAT (2007) La vita quotidiana nel 2006, Informazioni - 12, Roma: ISTAT.

LEE B. A., OROPESA R. S. and KANAN J. W. (1994) Neighborhood context and residential mobility, Demography 31 (2), 249-270.

LILLARD L. A. and PANIS C. W. A. (2003) AML Multilevel Multiprocess Statistical Software, Version 2.0. EconWare, Los Angeles, California.

LIVI BACCI M. (1980) Donna, fecondità e figli. Due secoli di storia demografica, Il Mulino, Bologna.

MANNHEIMER R., MICHELI G. A. and ZAJCZYK F. (1978) Mutamento sociale $e$ comportamento elettorale. Il caso del referendum sul divorzio, Franco Angeli, Milano. 
MASON W., WONG G. and ENTWISLE B. (1983) Contextual analysis through the multilevel linear model, in LEINHARDT S. (Ed.) Sociological Methodology, pp. 72-103. Josey Bass, San Francisco.

MEGGIOLARO S. (2005) Intenzioni e Comportamento riproduttivo. Un'analisi congiunta delle determinanti individuali e di contesto. Ph.D. Thesis in Statistics Applied to the Economic and Social Sciences. Supervisor: Prof. F. Ongaro. Co-Supervisor: Prof. N. Torelli. Department of Statistical Sciences, University of Padova.

MENNITI A. (2001) Fertility intentions and subsequent behaviour: first results of a panel study, paper presented at the European Population Conference 2001, Helsinki.

MICHELI G. A. and RIVELLINI G. (2001) A significantly influent context: Suggestions for a theory-laden multilevel modeling? in Atti della XL Riunione Scientifica SIS, pp. 53-54. Università di Firenze, 26-28 April 2000, Firenze.

MONNIER A. (1987) Projets de fécondité et fécondité effective. Une enquête longitudinale: 1974, 1976, 1979, Population 6, 819-842.

MONTGOMERY M. R. and CASTERLINE J. B. (1998) Social networks and the diffusion of fertility control, Policy Research Division Working Paper No. 119, Population Council, New York.

ONGARO F. (2004) Servizi alle persone e comportamenti familiari, in BILLARI F. C. and MAURI L. (Eds.) Dinamiche familiari e bisogni sociali, survey sociodemografica in Alto Adige, pp. 143160. Franco Angeli, Milano.

ONGARO F. (2006) Scelte riproduttive fra costi, valori, opportunità. Franco Angeli, Milano.

RIVELLINI G. and ZACCARIN S. (1999) Comportamenti riproduttivi: biografie individuali e contesto in un'ottica multilevel, in DE SANDRE P., PINNELLI A. and SANTINI A. (Eds.) Nuzialità e fecondità in trasformazione, percorsi e fattori del cambiamento, pp. 651-665. Il Mulino, Bologna. 
ROSSI R. (2001) Fecondità e contesto: tra certezze e aspettative. Prime elaborazioni - dati provvisori. Comune di Milano, Settore Statistica, Milano dati- Serie Ricerche n. 1, Milano.

SALVINI S. (2004) Low Italian fertility: the Bonaccia of the Antilles? Genus 60 (1), 19-38.

SAMPSON R. J., MORENOFF J. D. and GANNON-ROWLEY T. (2002) Assessing "neighborhood effects": social processes and new directions in research, Annual Review of Sociology 28, 443-478.

SANTOW G. and BRACHER M. (2001) Deferment of the first birth and fluctuating fertility in Sweden, European Journal of Population 17 (4), 343-363.

SCHOEN R., ASTONE N. M., KIM Y. J. and NATHANSON C. A. (1999) Do fertility intentions affect fertility behaviour? Journal of Marriage and the Family 61, 790-799.

SEMISA D. (2003) Uno sguardo alla metodologia, in Fecondità e contesto: tra certezze e aspettative. Dalla “Seconda Indagine Nazionale sulla Fecondità” alla realtà locale, pp.232-247. Comune di Milano, Settore Statistica, Quaderno di documentazione e studio n. 38, Franco Angeli, Milano.

SKIRBEKK V., KOHLER H. P. and PRSKAWETZ A. (2004) Birth-month, school graduation and the timing of births and marriage, Demography 41 (3), 547-568.

SMITH H. L. (1989) Integrating theory and research on the institutional determinants of fertility, Demography 26 (2), 171-184.

SNIJDERS T. and BOSKER R. (1999) Multilevel Analysis. An Introduction to Basic and Advanced Multilevel Modelling, Sage Publications, London.

SORVILLO M. P. (1997) Differenze territoriali nella fecondità italiana, in GIORGI P. and STROZZA S. (Eds.) Studi di popolazione. Temi di ricerca nuova, pp. 51-64. Secondo Convegno dei giovani studiosi dei problemi di popolazione. 25-27 giugno 1996, Dipartimento di Scienze Demografiche, Università degli Studi di Roma “La Sapienza", Roma. 
SORVILLO M. P. and MARSILI M. (1999) Aspettative di fecondità, in DE SANDRE P., PINNELLI A. and SANTINI A. (Eds.) Nuzialità e fecondità in trasformazione, percorsi e fattori del cambiamento, pp. 667-682. Il Mulino, Bologna.

SYMEONIDOU H. (2000) Expected and actual family size in Greece: 1983-1997, European Journal of Population 16 (4), 335-352.

TESTA M. P. and GRILLI L. (2006) The influence of childbearing regional contexts on ideal family size in Europe, Population 61 (1-2), 99-127.

VAN DE KAA D. (2001) Postmodern fertility preferences: from changing value orientation to new behaviour. Global fertility transition, in BULATAO R. and CASTERLINE J. (Eds.) Global fertility transition, a supplement to vol. 27 of Population and Development Review, 290-331.

VIKAT A. (2004) Women's labor force attachment and childbearing in Finland, Demographic Research 3, 177-212.

VITALI O. and MERLINI A. (1999) La qualità della vita: metodi e verifiche, Rivista Italiana di Economia Demografia e Statistica LIII (2), 5-93.

WESTOFF C. F. and RYDER N. B. (1977) The predictive validity of reproductive intentions, Demography 14 (4), 431-453.

ZAJCZYK F. (1997) Il mondo degli indicatori sociali. La Nuova Italia Scientifica, Roma.

ZELLER R. A. and CARMINES E. G. (1980) Measurement in the Social Sciences, Cambridge University Press, Cambridge. 


\section{Appendix A}

Elementary data used in six thematic areas describing context.

\begin{tabular}{|c|c|c|}
\hline Thematic areas & Elementary indicators & $\begin{array}{c}\text { Data source and year of } \\
\text { reference }\end{array}$ \\
\hline $\begin{array}{l}\text { Demographic } \\
\text { structure }\end{array}$ & $\begin{array}{l}\text {-\% people over } 65 \text { in population } \\
-\% \text { children }(0-6) \text { in population } \\
-\% \text { individuals in family with } 2 \text { or more children } \\
-\% \text { individuals in young couples without children } \\
-\% \text { living alone } \\
-\% \text { children living in single-parent family } \\
-\% \text { people over } 60 \text { living alone } \\
-\% \text { married } \\
-\% \text { separated or divorced }\end{array}$ & 2001 Population Census \\
\hline \multirow[t]{2}{*}{$\begin{array}{l}\text { Services and } \\
\text { environmental } \\
\text { quality }\end{array}$} & $\begin{array}{l}\text { - Numbers of theatres, cinemas and library per sq. km } \\
\text { - Numbers of sport centres } \\
\text { - Presence of institution "Tempo per famiglie" } \\
\text { ("Time for families") (= community centres) } \\
\text { - Numbers of "centri didattici territoriali" ("local } \\
\text { teaching centres") per sq. km. } \\
\text { - \% of children unable to attend city-run nurseries } \\
\text { (on waiting-lists) }\end{array}$ & $\begin{array}{c}\text { Decentralised Sectors, } 2004 \\
\text { Childhood and Youth Informative } \\
\text { System (SIA), } 1999\end{array}$ \\
\hline & $\begin{array}{l}-\% \text { green areas } \\
-\% \text { areas with parks and gardens }\end{array}$ & Parks and Gardens Sector, 2004 \\
\hline \multirow[t]{2}{*}{ Social unease } & - \% truancy, school drop-outs, etc. & $\begin{array}{l}\text { School Registry Data Bank, } \\
\text { 2002-2003 }\end{array}$ \\
\hline & $\begin{array}{l}\text { - \% children in care } \\
-\% \text { children in community care } \\
\text { - \% children dependent on Family Social Services } \\
\text { - \% families with children receiving supplementary } \\
\text { benefits }\end{array}$ & SIA, 1999 \\
\hline $\begin{array}{l}\text { Socio-economic } \\
\text { context }\end{array}$ & $\begin{array}{l}\text { - \% 25-64 year-old population with university } \\
\text { degrees } \\
-\% 15-19 \text { year-old population employed } \\
-\% \text { unemployed } \\
-\% \text { dependent workers of total workers } \\
-\% \text { employed in high-qualification jobs } \\
-\% \text { houses in poor repair } \\
-\% \text { women in labour market } \\
-\% \text { women employed part-time }\end{array}$ & 2001 Population Census \\
\hline \multirow[t]{3}{*}{$\begin{array}{l}\text { Community } \\
\text { vitality }\end{array}$} & - Number of parish youth clubs & SIA, 1999 \\
\hline & $\begin{array}{l}\text { - Number of associations } \\
\text { - Number of district newspapers }\end{array}$ & Decentralised Sectors, 2004 \\
\hline & - Presence of playgrounds & Parks and Gardens Sector, 2004 \\
\hline $\begin{array}{l}\text { Electoral } \\
\text { behaviour }\end{array}$ & $\begin{array}{l}-\% \text { of registered voters voting for ten Electoral } \\
\text { Registers at elections }\end{array}$ & Electoral Data Bank, 2001 \\
\hline
\end{tabular}




\section{Appendix B}

Factor structure matrixes after VARIMAX rotations (factor analyses).

\section{Demographic structure}

- \% individuals in family with 2 or more children

- \% individuals in young couples without children

- \% living alone

- \% children living in single-parent family

- \% people over 60 living alone

- \% married

- \% separated or divorced

\section{Social unease}

- \% truancy, school drop-outs, etc.

- \% children in care

- \% children in community care

- \% children dependent on Family Social Services

- \% families with children receiving supplementary benefits

\section{Socio-economic context}

- \% 25-64 year-old population with university degrees

- \% 15-19 year-old population employed

- \% unemployed

- \% dependent workers of total workers

- \% employed in high-qualification jobs

- \% houses in poor repair

- \% women in labour market

- \% women employed part-time

\section{Electoral behaviour}

- \% of registered voters voting for extreme Left

- \% of registered voters voting for extreme Right

- $\%$ of registered voters voting for Left

- \% of registered voters voting for "Margherita*" (Left)

- $\%$ of registered voters voting for centre

- \% of registered voters voting for coalition between centre and

left-wing parties

- \% of registered voters voting for "Forza Italia*" (Right)

- \% of registered voters voting for "Lega Nord*" (Right)

- \% of registered voters voting for "Lista Bonino*" (Left)

\section{Factor 1} (family types)

$-0.7732$

$-0.7753$

0.7977

0.8233

$-0.2740$

$-0.8732$

0.8717

Factor 1
(more severe

unease situations)
Factor 2 (demographic ageing)

$-0.1430$

$-0.2131$

$-0.4969$

$-0.4147$

0.8964

$-0.3427$

0.4167
unease situations)

$-0.1246$

less severe

$\begin{array}{ll}0.7939 & 0.1822\end{array}$

$0.9145-0.0255$

0.5037

0.7907

0.6879

0.6817

Factor $1 \quad$ Factor 2

(socio-economic (female participation level)

$-0.9905$

in labour market)

0.0321

$0.9546-0.2045$

$0.8941 \quad-0.2561$

$0.9776 \quad 0.0218$

$\begin{array}{ll}-0.9933 & 0.0515\end{array}$

$0.8397 \quad 0.0358$

$0.0216 \quad 0.9832$

$-0.6945$

0.5093

\section{Factor 1}

(Right/left-wing parties)

0.9459

0.9459
-0.8735

0.8839

$-0.1694$

$-0.7359$

0.9131

$-0.8024$

0.7048

$-0.9395$

\section{Factor 2}

(conception of community solidarity)
$-0.0583$

0.0818

0.9363

0.1104

0.0217

$-0.0182$

$-0.4989$

0.1968

\footnotetext{
* Margherita, Forza Italia, Lega Nord and Lista Bonino represented major political parties in elections of Chamber of Deputies, 13 May 2001.
} 
Table 1. Characteristics of women (percentages) according to explanatory variables.

\begin{tabular}{|c|c|}
\hline Characteristics & $\%$ \\
\hline \multicolumn{2}{|l|}{ Age } \\
\hline Under 30 & 32.4 \\
\hline $30-34$ & 21.0 \\
\hline $39-39$ & 18.5 \\
\hline 40 or over & 28.1 \\
\hline \multicolumn{2}{|l|}{ Number of children } \\
\hline No children & 53.9 \\
\hline 1 child & 21.1 \\
\hline 2 or more children & 25.0 \\
\hline \multicolumn{2}{|l|}{ Marital status } \\
\hline Never married & 35.8 \\
\hline Married for less than 5 years $(\dagger)$ & 22.4 \\
\hline Married for more than 5 years & 35.7 \\
\hline Divorced/separated/widowed & 6.1 \\
\hline \multicolumn{2}{|l|}{ Employment status } \\
\hline Employed & 74.9 \\
\hline \multicolumn{2}{|l|}{ Education } \\
\hline High (university) & 28.8 \\
\hline Middle (high school) & 46.5 \\
\hline Low (primary school or less) & 24.7 \\
\hline \multicolumn{2}{|l|}{ Church attendance } \\
\hline At least once a week & 21.4 \\
\hline Once a month & 13.9 \\
\hline Only for important feast days/almost never & 39.9 \\
\hline Not religious & 24.8 \\
\hline \multicolumn{2}{|l|}{ Parents' experience of separation or divorce } \\
\hline Yes & 9.9 \\
\hline \multicolumn{2}{|l|}{ Parents' children } \\
\hline 1 child & 18.1 \\
\hline 2 children & 39.4 \\
\hline 3 children & 19.1 \\
\hline 4 or more children & 23.4 \\
\hline \multicolumn{2}{|c|}{ Presence of friends to call upon for small needs } \\
\hline None & 19.2 \\
\hline \multicolumn{2}{|l|}{ Reproductive intentions } \\
\hline Yes, within 3 years & 24.2 \\
\hline Yes, over next 3 years & 22.4 \\
\hline Uncertain & 15.6 \\
\hline None & 37.8 \\
\hline
\end{tabular}

$(\dagger)$ Here and in the following analyses, this category includes women who declared they plan to marry within 2 years of the interview. 
Table 2. Percentages of women who intended to have children within next three years, by district of residence, sample sizes and some characteristics of districts.

\begin{tabular}{lcccc}
\hline $\begin{array}{l}\text { District } \\
\text { no. }\end{array}$ & $\begin{array}{c}\text { \% of women who } \\
\text { intended to have } \\
\text { children within next } \\
\text { three years }\end{array}$ & $\begin{array}{c}\text { Sample } \\
\text { size }\end{array}$ & Population & Sq. km \\
\hline $\mathbf{1}$ & 26.7 & 60 & 78,364 & 8.3 \\
$\mathbf{2}$ & 31.0 & 29 & 68,212 & 5.6 \\
$\mathbf{3}$ & 27.3 & 33 & 48,492 & 2.5 \\
$\mathbf{4}$ & 21.9 & 41 & 64,663 & 4.6 \\
$\mathbf{5}$ & 14.6 & 41 & 56,095 & 4.1 \\
$\mathbf{6}$ & 24.6 & 57 & 98,264 & 6.4 \\
$\mathbf{7}$ & 13.6 & 22 & 31,598 & 4.4 \\
$\mathbf{8}$ & 33.3 & 27 & 45,888 & 6.9 \\
$\mathbf{9}$ & 19.2 & 26 & 46,511 & 7.3 \\
$\mathbf{1 0}$ & 24.6 & 65 & 92,423 & 9.1 \\
$\mathbf{1 1}$ & 27.9 & 54 & 92,747 & 5.4 \\
$\mathbf{1 2}$ & 35.0 & 20 & 27,382 & 8.8 \\
$\mathbf{1 3}$ & 38.5 & 20 & 23,332 & 9.6 \\
$\mathbf{1 4}$ & 14.3 & 35 & 70,670 & 20.1 \\
$\mathbf{1 5}$ & 39.3 & 28 & 51,192 & 9.5 \\
$\mathbf{1 6}$ & 16.1 & 31 & 51,035 & 11.8 \\
$\mathbf{1 7}$ & 27.3 & 44 & 76,046 & 6.9 \\
$\mathbf{1 8}$ & 21.7 & 60 & 81,850 & 19.8 \\
$\mathbf{1 9}$ & 20.6 & 63 & 88,964 & 16.3 \\
$\mathbf{2 0}$ & 20.6 & 34 & 77,175 & 14.0 \\
\hline & & & & \\
\hline
\end{tabular}


Table 3. Contextual dimensions, thematic areas, synthesis techniques and descriptive statistics of contextual indexes.

\begin{tabular}{|c|c|c|c|c|c|c|c|}
\hline $\begin{array}{l}\text { Contextual } \\
\text { dimensions }\end{array}$ & Thematic areas & $\begin{array}{l}\text { Synthesis } \\
\text { techniques }\end{array}$ & Contextual indexes & Mean & Std. Dev. & Min. & Max. \\
\hline \multirow{2}{*}{$\begin{array}{l}\text { Role of social } \\
\text { norms }\end{array}$} & \multirow{2}{*}{$\begin{array}{l}\text { Demographic } \\
\text { structure }\end{array}$} & \multirow{2}{*}{$\begin{array}{l}\text { Method based on } \\
\text { factor analysis }\end{array}$} & $\begin{array}{c}\text { Factor } 1 \\
\text { (family types) }\end{array}$ & 0.0 & 1.0 & -1.385 & 2.276 \\
\hline & & & $\begin{array}{c}\text { Factor } 2 \\
\text { (demographic ageing) }\end{array}$ & 0.0 & 1.0 & -2.017 & 1.619 \\
\hline $\begin{array}{l}\text { Cost-benefit } \\
\text { analysis }\end{array}$ & $\begin{array}{c}\text { Services and } \\
\text { environmental } \\
\text { quality }\end{array}$ & $\begin{array}{l}\text { Method based on an } \\
\text { order procedure }\end{array}$ & $\begin{array}{l}\text { Index of services and } \\
\text { environmental quality }\end{array}$ & 0.329 & 0.117 & 0.142 & 0.528 \\
\hline \multirow{5}{*}{$\begin{array}{l}\text { Trust in or fear } \\
\text { of future }\end{array}$} & \multirow{2}{*}{ Social unease } & \multirow{2}{*}{$\begin{array}{l}\text { Method based on } \\
\text { factor analysis }\end{array}$} & $\begin{array}{c}\text { Factor } 1 \\
\text { (more severe unease situations) }\end{array}$ & 0.0 & 1.0 & -0.971 & 2.399 \\
\hline & & & $\begin{array}{c}\text { Factor } 2 \\
\text { (less severe unease situations) }\end{array}$ & 0.0 & 1.0 & -1.459 & 2.615 \\
\hline & \multirow{2}{*}{$\begin{array}{c}\text { Socio-economic } \\
\text { context }\end{array}$} & \multirow{2}{*}{$\begin{array}{l}\text { Method based on } \\
\text { factor analysis }\end{array}$} & $\begin{array}{c}\text { Factor } 1 \\
\text { (socio-economic level) }\end{array}$ & 0.0 & 1.0 & -2.416 & 1.050 \\
\hline & & & $\begin{array}{c}\text { Factor } 2 \\
\text { (female participation in labour market) }\end{array}$ & 0.0 & 1.0 & -2.385 & 1.246 \\
\hline & Community vitality & $\begin{array}{l}\text { Method based on an } \\
\text { order procedure }\end{array}$ & Index of community vitality & 0.262 & 0.122 & 0.028 & 0.519 \\
\hline \multirow{2}{*}{$\begin{array}{l}\text { Cultural } \\
\text { dimension }\end{array}$} & \multirow{2}{*}{$\begin{array}{c}\text { Electoral } \\
\text { behaviour }\end{array}$} & \multirow{2}{*}{$\begin{array}{l}\text { Method based on } \\
\text { factor analysis }\end{array}$} & $\begin{array}{c}\text { Factor } 1 \\
\text { (right/left-wing parties) }\end{array}$ & 0.0 & 1.0 & -2.328 & 1.526 \\
\hline & & & $\begin{array}{c}\text { Factor } 2 \\
\text { (conception of community solidarity) }\end{array}$ & 0.0 & 1.0 & -1.589 & 1.906 \\
\hline
\end{tabular}


Table 4. Individual factors influencing probability of intending to have a child within three years, according to logistic model (790 observations).

\begin{tabular}{|c|c|c|}
\hline & b coefficients & $\begin{array}{c}\text { Standard } \\
\text { Errors }\end{array}$ \\
\hline Intercept & $-2.59 * * *$ & 0.622 \\
\hline \multicolumn{3}{|l|}{ Age (reference: over 40) } \\
\hline Under 30 & $1.12 * * *$ & 0.369 \\
\hline $30-34$ & $1.80 * * *$ & 0.299 \\
\hline $35-39$ & $1.02 * * *$ & 0.303 \\
\hline \multicolumn{3}{|l|}{ Number of children (reference: 0 children) } \\
\hline 1 child & -0.29 & 0.273 \\
\hline 2 or more children & $-1.54 * * *$ & 0.351 \\
\hline \multicolumn{3}{|l|}{ Marital status (reference: never married) } \\
\hline Married for less than 5 years & $1.17 * * *$ & 0.243 \\
\hline Married for more than 5 years & -0.11 & 0.364 \\
\hline Divorced/separated/widowed & -0.71 & 0.473 \\
\hline \multicolumn{3}{|l|}{ Employment status (reference: Unemployed) } \\
\hline Employed & 0.44 & 0.243 \\
\hline \multicolumn{3}{|l|}{ Education (reference: High) } \\
\hline Low & 0.27 & 0.305 \\
\hline Middle & 0.04 & 0.250 \\
\hline \multicolumn{3}{|l|}{ Church attendance (reference: Not religious) } \\
\hline At least once a week & 0.01 & 0.324 \\
\hline Once a month & 0.49 & 0.273 \\
\hline Only for important feast days/almost never & 0.13 & 0.254 \\
\hline \multicolumn{3}{|c|}{ Parents' experience of separation or divorce (reference: $\mathrm{No}$ ) } \\
\hline Yes & 0.33 & 0.269 \\
\hline \multicolumn{3}{|l|}{ Parents' children (reference: 4 or more children) } \\
\hline 1 child & -0.55 & 0.299 \\
\hline 2 children & -0.35 & 0.354 \\
\hline 3 children & -0.08 & 0.315 \\
\hline \multicolumn{3}{|c|}{ Presence of friends to call upon for small needs (reference: Yes) } \\
\hline None & 0.18 & 0.163 \\
\hline Association of predicted probabilities and observed responses: & Sensitivity: $0.31 \quad$ Specific & ty: 0.92 \\
\hline
\end{tabular}


Table 5. Individual and contextual determinants of short-term reproductive intentions: separate intercepts logistic model (790 observations).

\begin{tabular}{|c|c|c|}
\hline & coefficient & Standard Error \\
\hline Constant & $-2.35 * * *$ & 0.576 \\
\hline District (reference: district 1) & a coefficients & Standard Errors \\
\hline 2 & $-0.22 * *$ & 0.095 \\
\hline 3 & $-0.24 * * *$ & 0.082 \\
\hline 4 & $-0.34 * * *$ & 0.070 \\
\hline 5 & $-0.86 * * *$ & 0.098 \\
\hline 6 & $-0.42 * * *$ & 0.068 \\
\hline 7 & $-1.14 * * *$ & 0.088 \\
\hline 8 & 0.21 & 0.154 \\
\hline 9 & $-0.73 * * *$ & 0.116 \\
\hline 10 & $-0.41 * * *$ & 0.084 \\
\hline 11 & -0.02 & 0.094 \\
\hline 12 & $0.58 * * *$ & 0.126 \\
\hline 13 & 0.32 & 0.176 \\
\hline 14 & $-0.56 * * *$ & 0.131 \\
\hline 15 & $0.39 * * *$ & 0.118 \\
\hline 16 & $-0.97 * * *$ & 0.139 \\
\hline 17 & -0.13 & 0.068 \\
\hline 18 & $-0.65 * * *$ & 0.098 \\
\hline 19 & $-0.77 * * *$ & 0.091 \\
\hline 20 & $-0.53 * * *$ & 0.107 \\
\hline Individual characteristics & b coefficients & Standard Errors \\
\hline \multicolumn{3}{|l|}{ Age (reference: over 40) } \\
\hline Under 30 & $1.14 * * *$ & 0.386 \\
\hline $30-34$ & $1.84 * * *$ & 0.309 \\
\hline $35-39$ & $1.02 * * *$ & 0.317 \\
\hline \multicolumn{3}{|l|}{ Number of children (reference: 0 children) } \\
\hline 1 child & -0.29 & 0.272 \\
\hline 2 or more children & $-1.63 * * *$ & 0.387 \\
\hline \multicolumn{3}{|l|}{ Marital status (reference: Never married) } \\
\hline Married for less than 5 years & $1.19 * * *$ & 0.253 \\
\hline Married for more than 5 years & -0.08 & 0.392 \\
\hline Divorced/separated/widowed & -0.65 & 0.504 \\
\hline \multicolumn{3}{|l|}{ Employment status (reference: Unemployed) } \\
\hline Employed & $\mathbf{0 . 5 0}$ *** & 0.251 \\
\hline \multicolumn{3}{|l|}{ Education (reference: High) } \\
\hline Low & 0.26 & 0.299 \\
\hline Middle & 0.02 & 0.260 \\
\hline \multicolumn{3}{|l|}{ Church attendance (reference: Not religious) } \\
\hline At least once a week & 0.05 & 0.352 \\
\hline Once a month & 0.53 & 0.308 \\
\hline Only for important feast days/almost never & 0.23 & 0.267 \\
\hline \multicolumn{3}{|l|}{ Parents' experience of separation or divorce (reference: $\mathrm{No}$ ) } \\
\hline Yes & 0.36 & 0.260 \\
\hline \multicolumn{3}{|l|}{ Parents' children (reference: 4 or more children) } \\
\hline 1 child & -0.63 & 0.392 \\
\hline 2 children & -0.36 & 0.375 \\
\hline 3 children & -0.13 & 0.303 \\
\hline \multicolumn{3}{|l|}{ Presence of friends for small needs (reference: Yes) } \\
\hline None & 0.19 & 0.174 \\
\hline Association of predicted probabilities and observed responses: & Sensitivity: $0.38 \quad$ Specif & city: 0.93 \\
\hline
\end{tabular}


Table 6. Individual and contextual determinants of short-term reproductive intentions: contextual logistic model (790 observations).

\begin{tabular}{|c|c|c|}
\hline & b coefficients & Standard Errors \\
\hline Intercept & $-3.54 * * *$ & 0.511 \\
\hline \multicolumn{3}{|l|}{ Contextual characteristics } \\
\hline Family types & -0.01 & 0.128 \\
\hline Demographic ageing & 0.15 & 0.092 \\
\hline Services and environmental quality & -0.68 & 0.984 \\
\hline More severe situations of unease & -0.24 & 0.139 \\
\hline Less severe situations of unease & $-0.41 * *$ & 0.206 \\
\hline Socio-economic level & 0.04 & 0.266 \\
\hline Female participation in labour market & -0.45 & 0.244 \\
\hline Community vitality & $2.25 * * *$ & 0.382 \\
\hline Right/left-wing parties & -0.04 & 0.273 \\
\hline Conception of community solidarity & -0.09 & 0.086 \\
\hline \multicolumn{3}{|l|}{ Individual characteristics } \\
\hline \multicolumn{3}{|l|}{ Age (reference: over 40) } \\
\hline Under 30 & $1.15 * * *$ & 0.386 \\
\hline $30-34$ & $1.85 * * *$ & 0.305 \\
\hline $35-39$ & $1.02 * * *$ & 0.311 \\
\hline \multicolumn{3}{|l|}{ Number of children (reference: 0 children) } \\
\hline 1 child & -0.27 & 0.269 \\
\hline 2 or more children & $-1.56 * * *$ & 0.357 \\
\hline \multicolumn{3}{|l|}{ Marital status (reference: Never married) } \\
\hline Married for less than 5 years & $1.15 * * *$ & 0.242 \\
\hline Married for more than 5 years & -0.09 & 0.374 \\
\hline Divorced/separated/widowed & -0.64 & 0.496 \\
\hline \multicolumn{3}{|l|}{ Employment status (reference: Unemployed) } \\
\hline Employment & 0.48 & 0.249 \\
\hline \multicolumn{3}{|l|}{ Education (reference: High) } \\
\hline Low & -0.31 & 0.291 \\
\hline Middle & 0.05 & 0.253 \\
\hline \multicolumn{3}{|l|}{ Church attendance (reference: Not religious) } \\
\hline At least once a week & 0.08 & 0.343 \\
\hline Once a month & 0.55 & 0.296 \\
\hline Only for important feast days/almost never & 0.23 & 0.264 \\
\hline \multicolumn{3}{|c|}{ Parents' experience of separation or divorce (reference: No) } \\
\hline Yes & 0.34 & 0.254 \\
\hline \multicolumn{3}{|c|}{ Parents' children (reference: 4 or more children) } \\
\hline 1 child & -0.60 & 0.473 \\
\hline 2 children & -0.33 & 0.354 \\
\hline 3 children & -0.11 & 0.295 \\
\hline \multicolumn{3}{|c|}{ Presence of friends to call upon for small needs (reference: Yes) } \\
\hline None & 0.19 & 0.162 \\
\hline Association of predicted probabilities and observed $\mathrm{r}$ & ity: 0.34 Specific & \\
\hline
\end{tabular}


Figure 1. Administrative division of Milan into 20 districts.

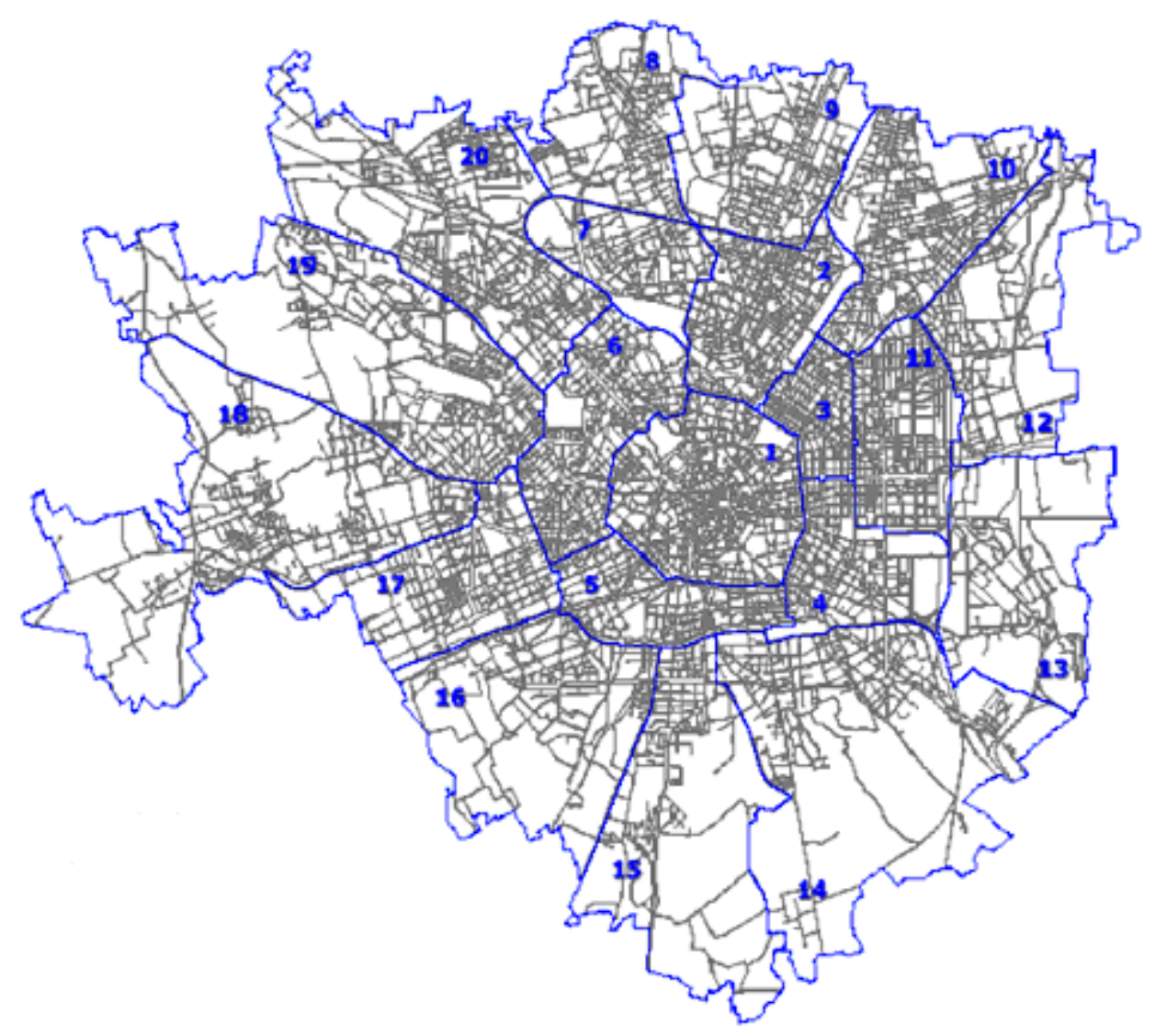


Figure 2. Administrative division of Milan into 20 districts and percentages of women who intend to have children within the next three years, by district.

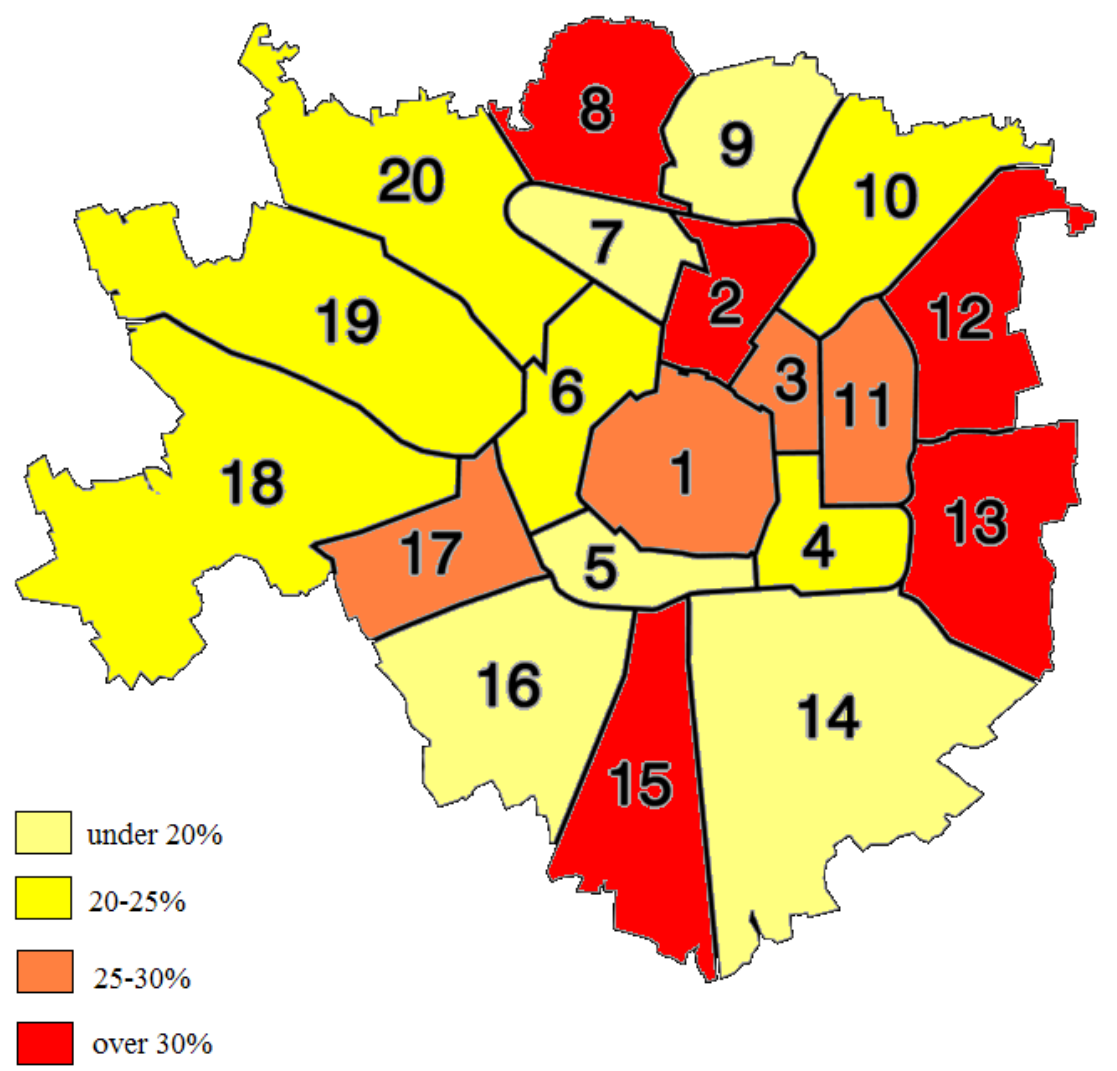


Figure 3. Significant different intercepts in comparison with coefficients for district 1 (separate intercepts logistic model-table 5).

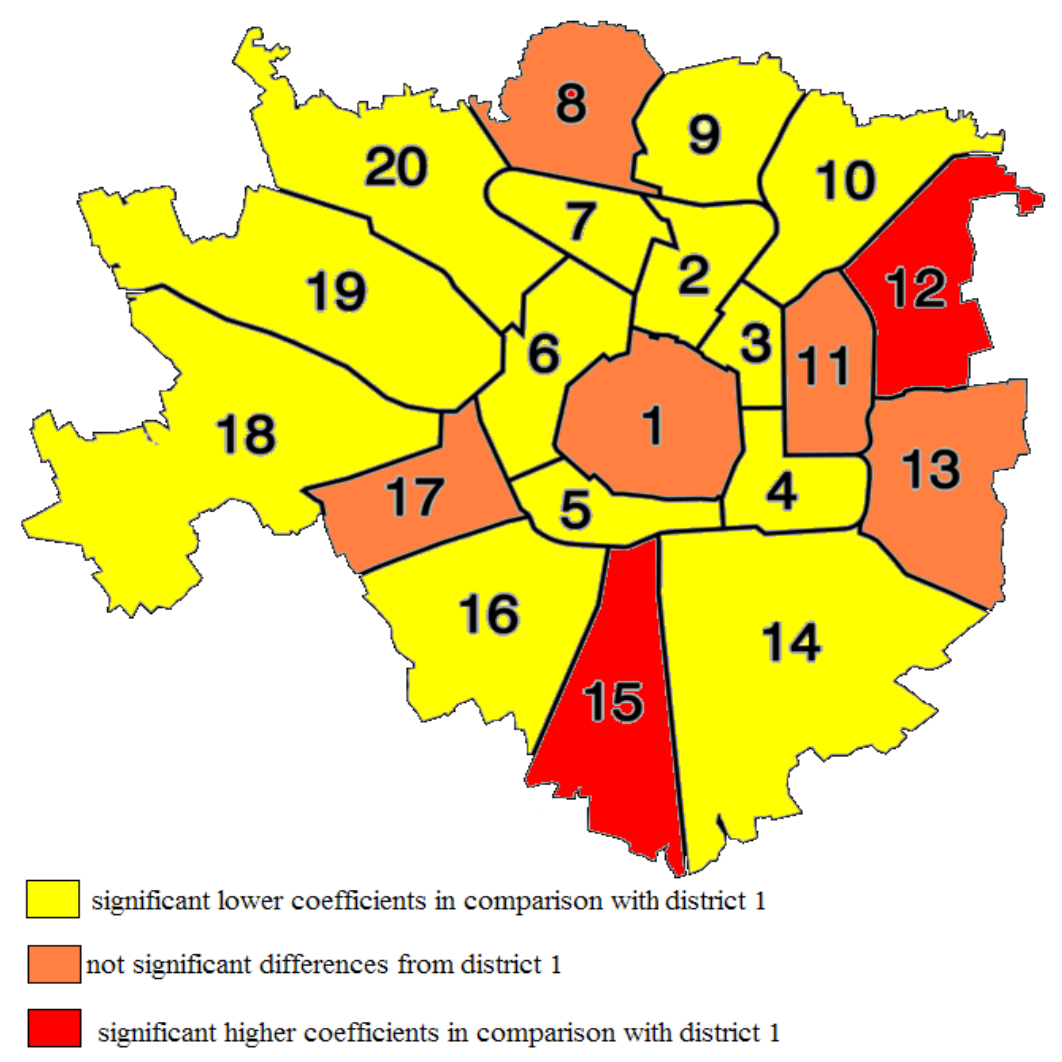

